\title{
Review \\ MELISSOPALYNOLOGY IN BRAZIL: A REVIEW OF POLLEN ANALYSIS OF HONEYS, PROPOLIS AND POLLEN LOADS OF BEES
}

\author{
Ortrud Monika Barth \\ UFRJ - Instituto de Biologia, Depto. de Botânica - CCS, Bloco A, Ilha do Fundão, 21949-900 - Rio de Janeiro, RJ - \\ Brasil. \\ FIOCRUZ - Instituto Oswaldo Cruz, Depto. de Virologia - Avenida Brasil 4365, 21045-900 - Rio de Janeiro, RJ - \\ Brasil. \\ e-mail <barth@ioc.fiocruz.br>
}

\begin{abstract}
This paper reviews current knowledge on the occurrence of several types of pollen grains in the sediments of honey samples, propolis and bee loads of Apiinae and Meliponinae in Brazil. After a short historical introduction about research activities in Melissopalynology using Brazilian samples, bee products were analyzed in respect to the greater Brazilian regions (South, Southeast, Northeast and North), emphasizing monofloral honeys and the green propolis. Numerous bibliographic references and a short glossary of the technical terms used is presented.
\end{abstract}

Key words: honey pollen, propolis pollen, bee load pollen, analysis, Brazil

\section{MELISSOPALINOLOGIA NO BRASIL: UMA REVISÃO SOBRE ANÁLISES PALINOLÓGICAS DE MEL, PRÓPOLIS E BOLOTAS DE PÓLEN DE ABELHAS}

\begin{abstract}
RESUMO: Foram apresentados os conhecimentos atuais existentes sobre a ocorrência de tipos polínicos em sedimentos de amostras de mel e de própolis, bem como constantes de cargas corbiculares de abelhas Apiinae e Meliponinae no Brasil. Introduzidas por um breve histórico sobre pesquisas em Melissopalinologia realizadas com amostras brasileiras, foram analisadas amostras destes produtos apícolas segundo as grandes regiões brasileiras (Sul, Sudeste, Nordeste e Norte), salientando-se méis monoflorais e a própolis verde. Extensa bibliografia acompanha o levantamento de dados, bem como um glossário sobre termos técnicos usados.

Palavras-chave: pólen, mel, própolis, bolotas, cargas corbiculares
\end{abstract}

\section{INTRODUCTION}

Scientific curiosity about the origin of products elaborated by bees, as well as commercial advantages in determining their quality, stimulated research activities that use the knowledge of pollen grain morphology as a tool for investigation. Pollen grains occur unexpected in honeys when prepared by bees. While collecting nectar from flowers in the field, pollen grains are occasionally swallowed by bees and carried into the hive. There they are transferred together with the nectar from bee to bee into the storage cells to dry and turn to honey. In separate flights, bees collect pollen grains from flowers and carry them in the baskets of their behind legs into the hive for storage in other than honey cells. This is known as the "bee bread", and used for protein nutrition of larvae.

Monofloral honeys, also named unifloral honeys, are undoubtedly the most attractive. They are originated from only one plant species. In Brazil they are produced by imported bees, Apis mellifera L., or by native stingless bees, the Meliponinae. These honeys maintain always the same physico-chemical and organoleptic characteristics and are well appreciated for commerce. It is possible to determine their origin from flowers by the recognition of the dominant pollen grains.

In contraposition, bifloral honeys are coming from two species of bee plants and the heterofloral honeys, also named plurifloral and wild honeys, from the nectar of several plant species. They may be produced by either Apis or native bees. The properties of these honeys are much more variable, in relation to bee species, respective flowering and climatic factors.

Knowledge about pollen is important also to caracterize honeydew honeys, originated from exudates of Aphidae (plant louses) sucking plant sap. These liquids from insects are processed like floral nectars. Pollen grains transported by wind or sticking on the bee coats adhere to these substances. Nevertheless, the pollen grains 
of these sweet extrafloral liquids are only indicative of the phytogeographical origin of honeydews.

There is in Brazil another product, named cane honey, that is an extrafloral honey elaborated by bees from the sugar sap that sprouds from the sugar cane thatches after be cutted. In this case also, the pollen grains are only indicative of the phytogeographical origin.

To fulfill holes and to embalm predators died inside the hives, Apis bees prepare a product named propolis, composed of plant resin, bee wax and secretions of the head glands of worker bees. When elaborated by stingless bees, this product is named geopropolis and contains in addition clay, earth or soil material. Pollen grains are introduced into these products accidentally. They indicate the geographical origin of the propolis and geopropolis.

The diversity and the frequency of pollen grains are considered at first during the analysis of honey sediments, and constitute the pollen analysis of honey. Therefore, the pollen analysis of bee products (honey, pollen and propolis) consider the pollen grains, their morphological characteristics which lead to the indication of the species or the botanical taxa of their origin, as well as the quantity that may be an indicative of the quality.

Nevertheless, in relation to honeydew honeys and cane honeys, propolis and geopropolis present other structured elements in their sediments that require a palynological analysis. Therefore, the palynological analysis of the bee products consider, besides pollen grains, other structured elements as spores and fungi hyphae, algae, plant hairs, insect bristles, silica, clay and earth, starch and wax, that enrich data and knowledge of the quality of the product, from its origin to its processing.

Citations and lists of bee plants as possible food sources are not considered in the present review of Melissopalynology. They are related to blooming and bee calendars based only upon field observations, without laboratorial confirmation. Summaries of papers presented during congresses and scientific meetings were not considered.

\section{Historical remarks}

Pioneer, traditional and standard studies in Melissopalynology (Louveaux et al. 1970; 1978) consolidated the development of reports on the occurrence of pollen grains in honeys, propolis and bee loads in Europe (France, Germany and Switzerland). The first investigations in Brazil were made by Santos (1961a; 1961b; 1963; 1964) on pollen grains of bee plants and honeys collected in the region of Piracicaba, SP, followed by studies of Barth (1969; 1970a; 1970b; 1970c; 1971a; 1971b; 1973; 1996) in different regions of the country. The position of Palynology in Brazil was presented during the First LatinAmerican Congress of Botany by Barth (1972), including extensive references and all the data of Melissopalynology available at the time. Subsequently,
Barth (1989; 1990a; 1996), Barth \& Luz (1998), Barth \& Coré-Guedes (1999), and Barth \& Dutra (2000), studied mainly the Southeast region.

Botanical studies in Melissopalynology by Absy \& Kerr (1977) were carried at the Instituto Nacional de Pesquisas da Amazônia (INPA), Manaus, with the aim of studying the Meliponinae or stingless bees in relation to bee plant resources in the Amazon region, and the palynological analyses of the respective honey samples and pollen loads. These investigations were followed by MarquesSouza (1993; 1996; 1999), Marques-Souza et al. (1993; 1995; 1996; 2002), and Marques-Souza \& Kerr (2003).

Several publications were presented about the pollen collected by Meliponinae in the state of São Paulo (Kleinert-Giovannini \& Imperatriz-Fonseca, 1987; Cortopassi-Laurino \& Ramalho, 1988; Ramalho, 1990), as well as by Apis (Santos, 1964; 1978), and the respective honeys (Santos, 1961b; 1964; 1978). In the region around the city of Belo Horizonte, MG, Bastos \& Brandão (1994) investigated the vegetation for bees and performed pollinic and chemical analyses of honeys (Bastos, 1993), and also of the green propolis (Bastos, 2001; Bastos et al., 2000).

More recently, in the state of Pará, Carreira et al. (1986), and Carreira \& Jardim (1994) studied honey samples of Apis. In the state of São Paulo, Carvalho \& Marchini (1999), Carvalho et al. (2001), Marchini et al. (2000) and Moreti et al. (2000; 2002) analyzed honeys of Apis and Meliponinae, as well as pollen loads and the corresponding flowering for bees. The trophic resources for Apis in the state of Roraima were investigated by Silva (1998) and Silva \& Absy (2000), and in the state of Rondônia, by Marques-Souza et al. (1993).

There are a few more publications on this matter, but no other group of investigators was consolidated. Condensed abstracts in several Congresses and extensive lists of regional bee floras and pastures were presented. Commonly, scientific corroboration was not present. Finally, chemists and pharmacists analyzed the proprieties and chemical characteristics of honeys, propolis and pollen using palynological analysis to obtain an exact identification and characterization of the samples (Costa et al., 1999).

The melissopalynological knowledge has been used uncommonly for qualification and market of bee products in Brazil by cooperative and beekeeper associations in several states. It would be desirable to have a more rigorous technical-scientific inspection.

\section{Regional considerations}

\section{Honey analyses}

As a consequence of the great extension of the country there is in Brazil a great variety of honeys, so that it is not possible to come to generalized conclusions. 
This matter is always of regional concern, with the tendency to address "micro" regions of honey production. The following results are based upon publications in scientific periodicals and books. They do not consider summarized data presented in congresses and scientific meetings, nor notes of journals or newspapers.

\section{South region}

References about pollen analysis of honeys from South Brazil are not frequent. Based on current knowledge, honeys that characterize the South region of Brazil are from Asteraceae (Compositae), in special Senecio brasiliensis, "maria-mole" (Barth, 1990a) and Lithrea sp., "aroeira". The taxa of Asteraceae, Eucalyptus, Myrtaceae and Mimosa scabrella occur frequently (Barth, 1969; 1989; Barth et al., 1999).

The relation between bees and pollen morphology of plant species of Loasaceae (Wittmann \& Schlindwein, 1995), Cactaceae (Schlindwein, 1995) and Pontederiaceae (Santos, 1997) were studied in the state of Rio Grande do Sul. The state of Santa Catarina is also an important producer of honey and bee products. Knowledge on pollen grains in honeys, of pollen loads and in propolis are scarce. Bracatinga (Mimosa scabrella) honey containing honeydew from the state of Santa Catarina was analyzed by Campos (1999). The pollen spectrum of samples of honeys from the state of Paraná (Ramalho et al., 1991) can be summarized in Allophylus, Baccharis, Campomanesia, Cecropia, Citrus, Eucalyptus, Matayba, Mimosa scabrella, Paspalum and Vernonia, therefore strongly heterofloral, but with the major occurrence of Eucalyptus.

\section{Southeast region}

The first honey analyses of Apis were performed by Santos $(1961 b ; 1964 ; 1978)$ in Piracicaba, State of São Paulo. The pollen spectrum was composed mainly by Eucalyptus, added by Agave sisalana, Baccharis, Dombeya and Persea. Ramalho et al. (1991) mentioned as the most important pollen types of honeys in the state of São Paulo the taxa Cecropia, Citrus, Eucalyptus, Paspalum and Syagrus. The pollen in honeys of Meliponinae presented a very rich and heterogeneous spectrum of plant taxa, in special Alchornea, Eucalyptus, Petroselinum and Schinus (Iwama \& Melhem, 1979; Ramalho, 1990).

In relation to the pollen collected by bees, Santos $(1964 ; 1978)$ found sources similar to the pollen identified in honeys, while Cortopassi-Laurino \& Ramalho (1988) reported Caesalpiniaceae, Cecropia, Eucalyptus, Mikania and Tipuana, and Marchini et al. (2000), Arecaceae, Asteraceae (mainly Bidens sp.), Eucalyptus sp., Mimosa caesalpiniaefolia, Ricinus communis and Zea mays. The trophic sources of Meliponinae bees were largely studied. Pollen loads represent a wide range of bo- tanical origins and very important are those of Eucalyptus (Carvalho \& Marchini, 1999; Cortopassi-Laurino \& Ramalho, 1988; Cortopassi-Laurino \& Gelli, 1991; Imperatriz-Fonseca et al., 1989).

Barth (1970d) defined the characteristic pollen spectrum for honeys of the state of Rio de Janeiro as an association of Baccharis, Citrus, Eucalyptus, Hyptis, Ricinus and Triumfetta. Monofloral honeys of Borreria verticillata, Citrus, Eucalyptus, Hyptis umbrosa and Vernonia scorpioides were identified by Barth (1970a). The analysis of mangrove honeys (Barth \& Luz, 1998; Luz $\&$ Barth, 2001) revealed a pollen spectrum of Eupatorium, Gochnatia, Mimosa bimucronata/M. caesalpiniaefolia, Mimosa pudica and Sapindaceae, while pollen collected as loads was coming mainly from $E u$ patorium, Ricinus and Sapindaceae. There was no significant participation of plant species characteristic of mangue vegetation. Bifloral honeys of Citrus and Eucalyptus of the states of Rio de Janeiro and São Paulo were analyzed by Barth \& Coré-Guedes (1999). In the region of Bananal, between the two states, Dutra \& Barth (1997) detected a very heterogenous association of botanical taxa; same is true for Chaves (1995) in the region of Secretário.

Melissopalynological data from the state of Espírito Santo were not found in the scientific literature. The analysis of a single honey sample (data not published) reflected the presence of the widespread coffee (Coffea sp.) plantations in the region, and their pollen grains were associated to wild plant species, mainly Asteraceae.

Honeys, pollen and propolis of the state of Minas Gerais were extensively examined by Bastos (1993; 1995), Bastos \& Brandão (1994), Bastos et al. (1991; 1995; 1996; 2000), Brandão \& Bastos (1995) and Brandão et al. (1993). The honey samples were obtained in the regions of Barão dos Cocais, Bom Jesus, Caraça, São Gonçalo and Serra da Piedade, and were considered in relation to dry and humid climatic conditions during several years. The pollen of Eucalyptus dominated over several species widely cultivated in the state, and in one particular case, it was reached by bees over a distance of $10 \mathrm{~km}$. Significant quantity of pollen grains of Alternanthera, Antigonon, Baccharis, Borreria, Croton, Eupatorium, Hyptis, Schinus, Serjania, Terminalia, Trichogonia and Vernonia were also detected. Barth (1970a) reported a monofloral honey with pollen of the Mimosa scabrella type obtained also in the state of Minas Gerais.

\section{Northeast region}

Barth (1969) found the dominant pollen of Astronium in a honey sample of the Northeast region. The major number of Apis honey samples proceeded from the state of Bahia (Barth, 1970a) with a pollen association 
of Acacia, Mimosa scabrella type, Eupatorium, Hyptis and Montanoa, the first two taxa of dominant and the other of accessory pollen grains. The pollen of Piptadenia moniliformis, a plant species with a large dispersion in the Northeast and that provides the famous "marmeleiro" honey (the honey sold under this name is in general a mixture of nectars from Piptadenia moniliformis and Croton sp.) dominated another sample. Moreti et al. (2000) found as dominant the pollen grains of Bauhinia sp. and Eucalyptus sp., and the pollen types of Mimosa scabrella and Mimosa verrucosa, and as accessory pollen, Alternanthera, Asteraceae and Cecropia. Carvalho et al. (2001) identified in honeys of Meliponinae the dominant pollen of Eucalyptus and Psidium. Sodré et al. (2001) identified 27 pollen types in 36 samples of honey from Apis, and as dominant pollen, the taxa of Arecaceae, Citrus, Cordia, Eucalyptus, Lithrea, Mimosa scabrella, Mimosa verrucata and Psidium. In the state of Ceará, Barth (1971a) found the association of Borreria verticillata and Piptadenia moniliformis as dominant, together with the accessory pollen types of Mimosa, Alternanthera, Copaifera and Salvia. Some honey samples of Ceará were analyzed by Freitas (2001), three of them were monofloral of Cocos nucifera, Alternanthera tenella and Eucalyptus sp., respectively, and predominantly species of Mimosaceae in heterofloral honeys. Honey samples of Meliponinae in the state of Maranhão (Kerr et al., 1986/ 87) presented variable pollen spectra, without dominance of any taxon.

\section{North region}

Extensive pollen studies of honey (Absy et al., 1980; Marques-Souza \& Kerr, 2003) and pollen from inside hives of Meliponinae and of pollen loads (Absy \& Kerr, 1977; Absy et al., 1984; Marques-Souza, 1993, 1996, 1999; Marques-Souza et al., 1995, 1996; 2002; Santos, 1991) were carried out mainly in areas next to Manaus, state of Amazonas. A large variety of pollen grains was identified in these samples, depending upon blooming. These bees visit many plant species, and explore only few resources and turn to be selective in accordance to the botanical offer (Marques-Souza, 1996). The most frequent taxa identified between more than 120 recognized in pot samples of pollen grains were Artocarpus, Bellucia, Carica, Cassia, Cocos, Leucaena, Maximiliana, Miconia, Myrtaceae, Stachytarpheta and Triplaris, with emphasis on Protium, both in honeys and in pots.

Honey samples of Apis of the state of Pará were analyzed by Carreira et al. (1986; Carreira \& Jardim, 1994). They found as dominant pollen the taxa of Caesalpiniaceae, Mimosa pudica and Tapirira guianensis. In addition Oliveira $(1997 ; 2003)$ and Oliveira et al. (1998) found the pollen of Borreria verticillata.
Marques-Souza et al. (1993) analyzed the pollen collected by Apis in Ji-Paraná, state of Rondônia. Between 126 recognized pollen types, only 12 taxa were intensively explored, mainly Cecropia sp., Cissus sp., Cocos nucifera, Cosmos caudatus, Cynometra sp., Mimosa pudica, Orbignya martiana and Poaceae in pasturelands and less disturbed areas. In the state of Roraima, Silva (1998) and Silva \& Absy (2000) analyzed honey of Apis with dominant pollen of Mimosa polydactyla and Curatella americana.

\section{Unspecified regions}

Various scientific papers refer to pollen analysis of honey samples from several regions of Brazil, frequently without any indication of origin. Barth (1969; 1970a; 1970b; 1970c; 1970d; 1970e; 1971a; 1971b; 1973; 1976; 1989; 1990a; 1996), Barth \& Dutra (2000), Barth et al. (1999) and Moreti et al. (2002), in relation to a collection of honey samples from various regions of the South, Southeast and Northeast of Brazil, identified monofloral honeys emphasizing those of Borreria verticillata, Croton, Eucalyptus, Mimosa scabrella type, Piptadenia moniliformis and Vernonia. Honeys of Citrus, from the states of Rio de Janeiro and São Paulo were evaluated in relation to the respective pollen spectra by Barth \& Coré-Guedes (1999). Considering the pollen concentration, that is the quantity of pollen grains comprised in one gram of honey, 17 samples of honey of Citrus and Eucalyptus obtained in the states of Minas Gerais, São Paulo and Rio de Janeiro were examined by Barth \& Dutra (2000). The absolute number of pollen grains per gram in monofloral honeys of Citrus varied from 776 to 2432, while in honeys of Eucalyptus, varied from 2588 to 17511 .

Regarding honey and pollen stored in pots by Meliponinae, Bazlen (2000) analyzed ten samples, most from the state of Bahia, and detected great diversity of botanical families visited by the bees, confirming the trend of bees to be generalist, but having preference for a few plant families. Some data were compared to some honey samples of more selective Apis bees. After extensive chemical analyses it was concluded that the properties and characteristics of Meliponinae honeys depend on the bee species and not on the blooming, as for Apis honey.

Chemical analyses of honey samples based upon the botanical diagnosis of origin, were made by Costa et al. (1999), Da Costa Leite et al. (2000), Duran et al. (1996), Horn (1997), and Azeredo et al. (2003). In all of them the importance of Eucalyptus honey standed out.

\section{Monofloral honeys}

The botanical origin of monofloral honeys - honeys coming from an unique plant species (or genus) - was confirmed by pollen analysis for honeys from several 
states of Brazil (Barth 1970a, 1990a, 1990b, 1996; Barth \& Dutra, 2000; Carreira et al., 1986; Carreira \& Jardim, 1994; Ramalho et al., 1991). Honey samples from the South region stand out by the Asteraceae (Senecio type), Mimosa scabrella and Myrtaceae (Myrcia type); for the Southeast region by Allophylus, Borreria verticillata, Campomanesia, Baccharis, Citrus, Croton, Eucalyptus, Eupatorium, Hyptis, Ilex, Matayba, Mimosa caesalpiniaefolia and Vernonia; for the Northeast region by Croton, Mimosa verrucosa, and Piptadenia moniliformis; and for the North region by Caesalpiniaceae, Mimosa pudica and Tapirira guianensis.

\section{Honeydew}

Honeydew was related to Eucalyptus (Barth, 1970e; Bastos, 1993) and to Mimosa bracatinga (Campos, 1999) and was present in honey samples of the states of Bahia, Ceará, Paraná and Rio de Janeiro (Barth, 1971b).

\section{Sugar cane honey}

Referred by Barth (1970e), sugar cane honey is characterized by a low incidence of nectariferous pollen grains, elevated incidence of anemophilous pollen grains (Poaceae, Cyperaceae, Cecropia), and by the prevailing in sediment volume of a granulous and colorless to light grey paste, originated from the cutted stems of sugar cane.

\section{Propolis}

Propolis samples from the states of Minas Gerais, Rio de Janeiro and Rio Grande do Sul were analyzed regarding the presence of morphological elements in their sediments by Barth (1998) and Barth et al. (1999). The main pollen types detected, besides a great quantity of trichomes, were Eucalyptus, Eupatorium and Mimosa caesalpiniaefolia. The high content of anemophilous pollen, in special of Cecropia, was highlighted.

Green propolis from six municipalities in the state of Minas Gerais were analyzed by Bastos (2001) and Bastos et al. (2000). The analysis pointed out the overall dominance of pollen of Eucalyptus, followed by pollen of Astronium, considered as characteristic of the "cerrado" (savanna) vegetation. The presence, however isolated, of Vellozia sp., should be indicative for the occurrence of a natural field vegetation in the area of propolis obtention. The pollen spectrum of these propolis samples from the state of Minas Gerais comprise Astronium sp., Baccharis dracunculifolia, Eucalyptus sp., Hyptis sp. and Vernonia polyanthes. The resin may be collected from leave buttons, mainly from Baccharis dracunculifolia and Vernonia polyanthes.

Absy \& Kerr (1977) observed that the Meliponinae, collected not only pollen grains but also resin, clay and, in separate loads, the latex of fruits of Vismia, for geopropolis confection. The presence of silica and clay and the absence of trichomes was used, besides pollen grains, to differentiate geopropolis of Meliponinae from propolis of Apis (Barth \& Luz, 2003).

\section{Chemical analyses of samples of honey and pollen}

Chemical analyses of honey samples, of which the botanical origin was investigated by pollen analysis, coming from several states of Brazil, were carried out by Almeida (2002), Arruda (2003), Azeredo et al. (2003), Costa et al. (1999), Da Costa Leite et al. (2000), Durán et al. (1996), Horn (1997), Komatsu (1996), Marchini (2001), Reis (2000), and Sodré (2000). Honey samples of Apis from the state of Minas Gerais were analyzed by Bastos et al. (1996), and regarding Meliponinae from the state of São Paulo by Cortopassi-Laurino \& Gelli (1991). Marques-Souza et al. (2002) made the chemical analysis of pollen collected by Meliponinae in the state of Amazonas.

\section{Honey and pollen of Meliponinae}

Several studies on the nutrition habits of the Meliponinae were made in the vicinity of Manaus, state of Amazonas, in the state of Bahia, and mainly in the state of São Paulo. Even though only few pollen analyses of honey sediments were performed, it was possible to identify more than 60 pollen types in a comparative study of the nutrition preferences of some species of Meliponinae in the region of Manaus (Absy et al., 1980), with prevalence of Protium, and in addition Alchornea, Alternanthera, Borreria, Cassia, Cecropia, Eugenia, Miconia, Mimosa scabrella type, Tapirira and Vismia. In a honey sample of the "uruçu" Meliponidae from Bahia (Carvalho et al., 2001), dominant pollen grains came from Eucalyptus and Psidium, together with Bauhinia, Caesalpiniaceae and the Mimosa verrucosa type. Several studies of honey samples of Meliponinae in the state of São Paulo (Guibu et al., 1988; Iwama \& Melhem, 1979; Ramalho, 1990; Ramalho et al., 1985) reported great number of flowering species visited by the bees, but selectively, Alchornea, Arecaceae, Eucalyptus, Moraceae, Myrtaceae, Petroselinum and Schinus.

There is more information on pollen loads of Meliponinae and the pollen kept in pots inside the hives. The number of plant species visited in the region of Manaus and other parts of the Amazon is high. The dominant pollen varies in accordance to the area of harvest and season of the year. (Absy \& Kerr, 1977; Absy et al., 1984; Kerr et al., 1986/87; Marques-Souza, 1993, 1996, 1999; Marques-Souza et al., 1995, 1996, 2002; Santos, 1991). The diversity of visited plants in the region of São Paulo is also very high (Cortopassi-Laurino \& Ramalho, 1988; Guibu et al., 1988; Imperatriz-Fonseca et al., 1989; Kerr et al., 1986/87; Kleinert-Giovannini \& Imperatriz-Fonseca, 1987; Ramalho et al., 1985, 1989; 1990; 1994), with prominence for the pollen of Eucalyptus and Myrtaceae. 


\section{Analyses of pollen loads}

Pollen loads of bee baskets, as well as pollen harvested in the cells or pots inside beehives, were object of several studies. Researchers looked either for the trophic preferences or for pasture or local and regional bee flora.

Regarding Apis bees, in addition to pollen morphological studies, (Barth, 1973, 1989), Barth \& Luz (1998) e Luz \& Barth (2001), analyzed honey and pollen collected in a mangrove area next to the city of Rio de Janeiro. They frequently found in pollen loads the pollen of Eupatorium, Ricinus communis and Sapindaceae, together with Cecropia, Borreria, Gochnatia, Panicum, Spondias, Triumfetta and Vernonia. The pollen of Eucalyptus and of Mimosaceae (taxa identified: Albizzia lebbeck, Piptadenia sp., Schrankia sp., and the pollen types of Mimosa bimucronata/M. caesalpiniaefolia and $M$. pudica) were collected a few times. Even though, various of these taxa were considered polliniferous, their pollen has no significant actrativity to be stored separately in the hives, and these plants were visited by the bees only as a nectar source. Data regarding this kind of information were obtained also for several regions of the state of São Paulo (Cortopassi-Laurino \& Ramalho, 1988; Marchini et al., 2000; Moreti et al., 2002; Ramalho et al., 1991; Santos, 1961a, 1961b, 1964, 1978), Rondônia (Marques-Souza et al., 1993), and Roraima (Silva, 1998). The pollen morphology of plant species visited by Apis and Meliponinae in the South of Brazil consisted of a few families (Santos, 1997; Schlindwein, 1995; Wittmann \& Schlindwein, 1995).

The trophic resources of pollen loads of Meliponinae bees were analyzed in some Amazon regions by Absy \& Kerr (1977), Absy et al. (1984), MarquesSouza (1993; 1996; 1999), Marques-Souza et al. (1995; 1996; 2002) and Santos (1991); in Pará by Oliveira (2003); in Maranhão by Kerr et al. (1986/87); in São Paulo by Carvalho \& Marchini (1999), CortopassiLaurino \& Ramalho (1988), Kleinert-Giovannini \& Imperatriz-Fonseca (1987), Imperatriz-Fonseca et al. (1989), Marchini et al. (2000), Ramalho et al. (1985; 1989; 1990; 1994), and in Rio Grande do Sul by Santos (1997). Results point out to a great variety of trophic resources and generalized habits of pollen harvesting by the Meliponinae.

\section{Analysis of royal jelly}

Similarly to propolis and geopropils, royal jelly contains pollen grains in the same proportion (circa 5\%), and coming from hives in which pollen was used and harvested by the bees, and is a result of the respective bloomings (data from O.M. Barth, unpublished).

\section{Summary of the current knowledge}

Considering the Apis bees, the pollen found in dominant and accessory quantities in honey samples comes from regional bloomings and from a few plant species. In the South of Brazil predominates the pollen of Senecio; in the Southeast Citrus and Eucalyptus; in Minas Gerais, wild plants; in the Northeast, Asteraceae Croton, Eucalyptus, several species of Mimosa and Piptadenia moniliformis; in Amazon, Arecaceae, Mimosa, Protium and Tapirira. Regarding pollen loads, the variety of plant species is bigger, and frequently the pollen of anemophilous species like Cecropia and Poaceae are present. There are no published data for the Central-West region of Brazil.

Meliponinae, in general, visit a larger number of plant species. They may be also selective in this respect, in accordance to the flowering, for nectar and pollen obtention. In all these studies there is a lack of indices of pollen production by plant species, mainly for monofloral honeys and pollen loads.

\section{Future perspectives}

With forest devastation in progress, burning and extensive use of agrotoxic products, Brazilian apiculture faces great trouble in future. Another factor of impact, mainly for the small producer, is the theft and the vandalism of beehives. The production of monofloral honeys and pollen will be always of preference and related to migratory activities. They can follow the rational and economically viable natural resources and may by related to the polinization of crops (apples, cashew, Eucalyptus, guarana, coffee, oranges, etc.)

\section{Glossary of botanical taxa and palynological terms used in the present paper}

Accessory pollen. Pollen that occurs in honey sediments between $15 \%$ and $45 \%$ of the total of pollen grains (counting comprises at least 300 pollen grains per sample).

Apis. Genus of Hymenoptera, Apidae. The species Apis mellifera L. is widely exploited by humans since prehistorical times for honey, pollen, propolis, royal jelly and wax. It was introduced in Brazil by European immigrants, mainly germans, in the beginning of the $19^{\text {th }}$ century in the South of the country. Their hives are constructed with honeycombs that shelter the young, the honey and the pollen. These bees are important polinizators of introduced plants in Brazil, like Eucalyptus, apple and orange.

Bifloral honey. Honey with dominance of pollen of only two plant species.

Dominant pollen. Pollen that occurs in honey sediments in excess of $45 \%$ of the total of pollen grains (counting comprises at least 300 pollen grains per sample).

Family. Group of botanical genera of morphological and genetical affinities, with names ending always in "aceae". Exemples: Myrtaceae, Asteraceae, Arecaceae. 
Geopropolis. Product elaborated by Meliponinae bees, starting with wax, resin or vegetal latex, and clay or soil particles, to construct the entrance and coat of hives and to close openings.

Heterofloral or plurifloral or wild honey. Honey with no dominance of pollen of any plant species.

Honey. Product elaborated by bees starting out of flower nectar or other sweet plant exudations.

Honeydew. Product elaborated by bees starting out of exudations of plant sucking Aphidae, presenting always a reduced number of pollen grains.

Isolated pollen. Occurs in honey sediments with less than $15 \%$ of the total of pollen grains (counting comprises at least 300 pollen grains per sample).

Meliponinae. A group of genera of Hymenoptera, native of Brazil, named as stingless bees. Their hives are constructed as honeycombs for the young and as pots for honey and pollen. They are important and well adapted polinizators of our native vegetation.

Melissopalynology. Science that deals with pollen grains in relation to bees and bee products.

Monofloral or unifloral honey. Honey with dominance of pollen of a single plant species.

Palynological analysis. Study of pollen grains and other figurated elements as hyphae and spores of fungi, algae cells, starch grains, plant trichomes (glands) in honey, propolis and pollen load, resulting in the palynological spectra.

Pollen. A collective word that means a group of pollen grains. Exemple: the pollen of an anther, a flower, a tree, a local or regional vegetation.

Pollen analysis. Study of pollen grains in honey, propolis and pollen load of bees, resulting in the pollen spectra.

Pollen grain. The masculine unity of plant fertilization found in flower anthers.

Pollen type. Name given after analyzing botanical taxa or sediments, in which frequently appear morphologically equal or similar pollen grains, that may be related to an unique plant species, several species of a same taxon or to several taxa.

Propolis. Product made by honeybees of the genus Apis out of wax and vegetal resin for hive coating.

Royal jelly. Milk-like product secreted by head glands of young worker bees to nourish larvae which will become workers at just the third day of live, and to be queens and drones during all life.
Sugar cane honey. Honey that starts with liquids exuded of cut stalks of sugar cane, very rich in saccharose, containing a large number of anemophilous pollen grains.

Taxon, plural taxa. Taxonomical unit used in Systematic Botany.

Trichomes. Glandular hairs or tectors of plants, localized mainly on leaf surfaces.

\section{ACKNOWLEDGEMENTS}

To Augusta Carolina C.C. Moreti, Breno Magalhães Freitas, and Léa Maria Medeiros Carreira for copies of requested papers; to an referee for new data supplied; and to Cynthia F.P. da Luz, longtime cowork, for suggestions and critical review of the manuscript. To $\mathrm{CNPq}$, in recognition for financial support.

\section{REFERENCES}

Abbreviations referring to topics in the following papers: $\mathrm{A}=$ Apis $\mathrm{CH}=$ chemical analysis; $\mathrm{HD}=$ honeydew $\mathrm{HO}=$ honey; $\mathrm{M}=$ Meliponinae; $\mathrm{PO}=$ pollen loads; $\mathrm{PR}=$ propolis.

ABSY, M.L.; KERR W.E. Algumas plantas visitadas para obtenção de pólen por operárias de Melípona seminigra merrillae em Manaus. Acta Amazônica, v.7, p.309-315, 1977. (M, PO)

ABSY, M.L.; BEZERRA, E.B.; KERR, W.E. Plantas nectaríferas utilizadas por duas espécies de Melipona da Amazônia. Acta Amazônica, v.10, p.271-281, 1980. (M, HO)

ABSY, M.L.; CAMARGO, J.M.F.; KERR W.E.; MIRANDA, I.P.A. Espécies de plantas visitadas por Meliponinae (Hymenoptera: Apoidea), para coleta de pólen na região do Médio Amazonas. Revista Brasileira de Biologia, v.44, p.227-237, 1984. (M, PO)

ALMEIDA, D. Espécies de abelhas (Hymenoptera: Apoidea) e tipificação dos méis por elas produzidos em área de cerrado no município de Pirassununga, estado de São Paulo. Piracicaba: USP/ESALQ, 2002. 103p. (Dissertação - Mestrado). (A, CH. HO)

ARRUDA, C.M.F. Características físico-químicas e polínicas de amostras de méis de Apis mellifera L., 1758 (Hymenoptera: Apidae) da região da Chapada do Araripe, município de Santana do Cariri, Estado do Ceará. Piracicaba: USP/ESALQ, 2003. 86p. (Dissertação - Mestrado). (A, CH, $\mathrm{HO})$

AZEREDO, L.C.; AZEREDO, M.A.A.; SOUZA, S.R.; DUTRA, V.M.L. Protein contents and physicochemical properties in honey samples of Apis mellifera of different origins. Food Chemistry, v.80, p.249-254, 2003. (A, HO)

BARTH, O.M. Pollenspektrum einiger brasilianischer Honige. Zeitschrift für Bienenforschung, v.9, p.410-419, 1969. (A, HO)

BARTH, O.M. Análise microscópica de algumas amostras de mel. 1. Pólen Dominante. Anais da Academia Brasileira de Ciências, v.42, p.351366, 1970a. (A, HO)

BARTH, O.M. Análise microscópica de algumas amostras de mel. 2. Pólen Acessório. Anais da Academia Brasileira de Ciências, v.42, p.571590, 1970b. (A, HO)

BARTH, O.M. Análise microscópica de algumas amostras de mel. 3. Pólen Isolado. Anais da Academia Brasileira de Ciências, v.42, p.747-772, 1970c. (A, HO)

BARTH, O.M. Análise microscópica de algumas amostras de mel. 4. Espectro polínico de algumas amostras de mel do Estado do Rio de Janeiro. Revista Brasileira de Biologia, v.30, p.575-582, 1970d. (A, $\mathrm{HO})$

BARTH OM. Análise microscópica de algumas amostras de mel. 5. Melato ("honeydew") em mel de abelhas. Revista Brasileira de Biologia, v.30, p.601-608, 1970e. (A, HD)

Sci. Agric. (Piracicaba, Braz.), v.61, n.3, p.342-350, May/June 2004 
BARTH, O.M. Análise microscópica de algumas amostras de mel. 6. Espectro polínico de algumas amostras de mel dos Estados da Bahia e do Ceará. Revista Brasileira de Biologia, v.31, p.431-434, 1971a. (A, HO)

BARTH, O.M. Mikroskopische Bestandteile brasilianischer Honigtauhonige. Apidologie, v.2, p.157-167, 1971b. (A, HD)

BARTH, O.M. Aspectos atuais e perspectivas futuras da Palinologia no Brasil. In: CONGRESSO LATINO-AMERICANO DE BOTÂNICA, 1. , México, 1972. Memórias dos simpósios. México, 1972. p.17-33.

BARTH, O.M. Rasterelektronenmikroskopische Beobachtungen an Pollenkoernern wichtiger brasilianischer Bienenpflanzen. Apidologie, v.4, p.317-329, 1973. (A, HO)

BARTH, O.M. O estudo do pólen no mel. O Apiário, v.14, p.19-23, 1976. (A, $\mathrm{HO})$

BARTH, O.M. O Pólen no mel brasileiro. Rio de Janeiro: Editora Luxor, 1989. 151p. (A, HO)

BARTH, O.M. Pollen in monofloral honeys from Brazil. Journal of Apicultural Research, v.29, p.89-94, 1990a. (A, HO)

BARTH, O.M. O pólen em méis monoflorais do Brasil. O Apiário, v.15, p.50-52, 1990b. (A, HO)

BARTH, O.M. Monofloral and wild flower honey pollen spectra at Brazil. Ciência e Cultura, v.48, p.163-165, 1996. (A, HO)

BARTH, O.M. Pollen analysis of Brazilian Propolis. Grana, v.37, p.97101, 1998. (A, PR)

BARTH, O.M.; LUZ, C.F.P. Melissopalynological data obtained from a mangrove area near to Rio de Janeiro, Brazil. Journal of Apicultural Research, v.37, p.155-163, 1998. (A, HO, PO)

BARTH, O.M.; CORÉ-GUEDES, J. Caracterização de méis de laranjeiras procedentes dos estados do Rio de Janeiro e de São Paulo, Brasil, por meio da análise polínica. LECTA, v.17, p.27-35, 1999. (A, HO)

BARTH, O.M.; DUTRA, V.M.L. Concentração de pólen em amostras de mel de abelhas monofloral do Brasil. Geociências. Revista da Universidade de Garulhos, n.esp., p.173-176, 2000. (A, HO)

BARTH, O.M.; DUTRA, V.M.L.; JUSTO, R.L. Análise polínica de algumas amostras de própolis do Brasil Meridional. Ciência Rural, v.29, p.663667, 1999. (A, PR)

BARTH, O.M.; LUZ, C.F.P. Palynological analysis of Brazilian geopropolis sediments. Grana, v.42, p.121-127, 2003. (M, PR)

BASTOS, E.M.A.F. Caracterização do espectro polínico e das propriedades físico-químicas dos méis produzidos em alguns campos antrópicos de Minas Gerais. Belo Horizonte: UFMG/FF, 1993. 104p. (Dissertação Mestrado). (A, HO)

BASTOS, E.M.A.F. Espectro polínico do mel produzido em algumas áreas antrópicas de Minas Gerais. Revista Brasileira de Biologia, v.55, p.789799, 1995. (A, HO)

BASTOS, E.M.A.F. Origem botânica e indicadores de qualidade da "própolis verde" produzida no Estado de Minas Gerais, Brasil. Ribeirão Preto: USP/FFCL, 2001. 137p. (Tese - Doutorado). (A, PR)

BASTOS, E.M.; BRANDÃO, M. Inventário da flora apícola de Barão dos Cocais, Minas Gerais- III. Daphne, v.4, p.54-60, 1994. (A, HO)

BASTOS, E.M.; BRANDÃO, M.; SILVEIRA, F.R.C. Espectro polínico dos méis produzidos no Parque Natural da Serra do Caraça - MG. Daphne, v.5, p.40-45, 1995. (A, HO)

BASTOS, E.M.; OLIVEIRA, V.D.C.; SOARES, A.E.E. Microscopic characterization of the green própolis, produced in Minas Gerais state, Brazil. Honeybee Science, v.21, p.179-180, 2000. (A, PR)

BASTOS, E.M.; GONÇALVES, T.; BATISTA, E,B.; BRANDÃO, M. Análise microscópica de amostras de mel do estado de Minas Gerais - I. Daphne, v.1, p.10-13, 1991. (A, HO)

BASTOS, E.M.; DAYRELL, I.; SAMPAIO, I.B.M.; JOLK, E. Correlation between pollen spectrum and physical-chemical properties of honeys production in Minas Gerais state (Brazil). Ciência e Tecnologia de Alimentos, v.16, p.145-152, 1996. (A, HO)

BAZLEN, K. Charakterisierung von Honigen stachelloser Bienen aus Brasilien. Tübingen: Eberhard Karls Universität/ Fakultät fur Biologic, 2000. 141p. (Thesis - Doktor). (A, CH, M, HO, PO)

BRANDÃO, M.; BASTOS, E.M. Espectro polínico do mel produzido na Serra da Piedade, Município de Caeté (MG). Daphne, v.5, p.10-14, 1995. (A, HO)

BRANDÃO, M.; BASTOS, E.M.; SILVEIRA, F.R.C. Inventário da flora apícola de São Gonçalo do Rio Abaixo, MG. Daphne, v.3, p.24-33, 1993. (A, HO)
CAMPOS. G. Análise laboratorial de mel de melato da bracatinga Informativo Zum-Zum, v.33, p.12, 1999. (A, CH, HD)

CARREIRA, L.M.M.; JARDIM, M.A.G. Análise polínica dos méis de alguns municípios do Estado do Pará - II. Boletim do Museu Paraense Emílio Goeldi. Série Botânica, v.10, p.83-88, 1994. (A, HO)

CARREIRA, L.M.M.; JARDIM, M.A.G.; MOURA, C.O.; PONTES M.A.O.; MARQUES, R.V. Análise polínica de méis de alguns municípios do Estado do Pará - I. In: SIMPÓSIO DO TRÓPICO ÚMIDO, 1., Belém, 1986. Anais. Belém: Embrapa, CPATU, 1986. p.79-84. (A, HO)

CARVALHO, C.A.L.; MARCHINI, L.C. Tipos polínicos coletados por Nannotrigona testaceicornis e Tetragonisca angustula (Hymenoptera, Apidae, Meliponinae). Scientia Agricola, v.56, p.717-722, 1999. (M, PO)

CARVALHO, C.A.L.; MORETI, A.C.C.C.; MARCHINI, L.C.; ALVES, R.M.O.; OLIVEIRA, P.C.F. Pollen spectrum of honey of "uruçu" bee (Melipona scutellaris Latreille, 1811). Revista Brasileira de Biologia, v.61, p.63-67, 2001. (M, HO)

CHAVES, S.A.M. Análise polínica do mel da região de Secretário, Petrópolis - RJ. Revista Brasileira de Apicultura, agosto-setembro/95: p.18-20, 1995. (A, HO)

CORTOPASSI-LAURINO, M.; RAMALHO, M. Pollen harvest by africanized Apis mellifera and Trigona spinipes in São Paulo: botanical and ecological views. Apidologie, v.19, p.1-24, 1988. (M, PO)

CORTOPASSI-LAURINO, M.; GELLI, D.S. Analyse pollinique, proprietés phisico-chimiques et actino antibactérienne des miels d'abeilles africanices Apis mellifera et de Méliponinés du Brèsil. Apidologie, v.22, p.61-73, 1991. (A, CH, HO, M)

COSTA, L.S.M.; ALBUQUERQUE, M.L.S.; TRUGO, L.C.; QUINTEIRO, L.M.C.; BARTH, O.M.; RIBEIRO, M.; DE MARIA, C.A.B. Determination of non-volatile compounds of different botanical origin Brazilian honeys. Food Chemistry, v.65, p.347-352, 1999. (A, CH, $\mathrm{HO})$

DA COSTA LEITE, J.M.; TRUGO, L.C.; COSTA, L.S.M.; QUINTEIRO, L.M.C.; BARTH, O.M.; DUTRA, V.N.L.; DE MARIA, C.A.B Determination of oligosaccharides in Brazilian honeys of different botanical origin. Food Chemistry, v.70, p.93-98, 2000. (A, CH, HO)

DURÁN, J.E.T.; CORTOPASSI-LAURINO, M.; ISSA, M.R.C.; TOLEDO, V.A.A.; BASTOS, E.; SOARES, A.E.E. Méis brasileiros: resultados de análises físico-químicas e palinológicas. In: CONGRESSO BRASILEIRO DE APICULTURA, 11., Teresina, 1996. Resumos. Teresina, 1996. p.403-429. (A, CH, HO)

DUTRA, V.M.L.; BARTH, O.M. Análise palinológica de amostras de mel da região de Bananal (SP/RJ), Brasil. Geociências. Revista Universidade Guarulhos, n.esp., p.174-183, 1997. (A, HO, PO)

FREITAS, B.M. Caracterização palinológica de algumas amostras de mel do Ceará. Ciência Agronômica, v.32, p.22-29, 2001. (A, HO)

GUIBU, L.S.; RAMALHO, M.; KLEINERT-GIOVANNINI, A.; IMPERATRIZ-FONSECA, V.L. Exploração dos recursos florais por colônias de Melípona quadrifasciata (Apidae, Meliponinae). Revista Brasileira de Biologia, v.48, p.299-305, 1988. (M, PO)

HORN, H. Méis brasileiros: resultados de análises físico-químicas e palinológicas. Mensagem Doce, v.40, p.10-16, 1997. (A, CH, HO)

IMPERATRIZ-FONSECA, V.L.; KLEINERT-GIOVANNINI, A.; RAMALHO, M. Pollen harvest by eusocial bees in a non-natural community in Brazil. Journal of Tropical Ecology, v.5, p.239-242, 1989. (M, PO)

IWAMA, S.; MELHEM, T.S. The pollen spectrum of the honey of Tetragonisca angustula angustula Latreille (Apidae, Meliponinae) Apidologie, v.10, p.275-295, 1979. (M, HO)

KERR, W.E.; ABSY, M.L.; MARQUES-SOUZA, A.C. Espécies nectaríferas e poliníferas utilizadas pela abelha Melípona crassipes fasciculata (Meliponinae, Apidae) no Maranhão. Acta Amazônica, v.16/17, p.145156, 1986/87. (M, PO)

KLEINERT-GIOVANNINI, A.; IMPERATRIZ-FONSECA, V.L. Aspects of the trophic niche of Melípona marginata marginata Lepeletier (Apidae, Meliponinae). Apidologie, v.18, p.69-100, 1987. (M, PO)

KOMATSU, S.S. Caracterização físico-química de méis de Apis mellifera L. 1758 (Hymenoptera: Apidae) de diferentes municípios do Estado de São Paulo. Piracicaba: USP/ESALQ, 1996. 90p. (Tese - Doutorado). (A, $\mathrm{CH}, \mathrm{HO})$

LOUVEAUX, J.; MAURIZIO, A.; VORWOHL, G. Methodik der Melissopalynologie. Apidologie, v.1, p.193-209, 1970. 
LOUVEAUX, J.; MAURIZIO, A.; VORWOHL, G. Methods of melissopalynology. Bee World, v.59, p.139-157, 1978.

LUZ, C.F.P.; BARTH, O.M. Melissopalynological observations in a mangrove area next to Rio de Janeiro, Brazil. In: PALYNOLOGICAL CONGRESS, 9., Houston, 1996. Proceedings. Houston: American Association of Stratigraphic Palynologists Foundation, 2001. p.489-492. (A, $\mathrm{HO}, \mathrm{PO})$

MARCHINI, L.C. Caracterização de amostras de méis de Apis mellifera L. 1758 (Hymenoptera: Apidae) do Estado de São Paulo, baseada em aspectos físico-químicos e biológicos. Piracicaba: USP/ESALQ, 2001. 101p. (Tese - Livre Docência). (A, CH, HO)

MARCHINI, L.C.; MORETI, A.C.C.C.; TEIXEIRA, E.W.; OLIVEIRA, P.C.F. Identificação das cargas de pólen transportadas por abelhas africanizadas (Apis mellifera L.) de diferentes colônias situadas num mesmo ambiente. Ecossistema, v.25, p.48-51, 2000. (A, PO)

MARQUES-SOUZA, A.C. Espécies de plantas visitadas para a coleta de pólen por cinco tipos de meliponíneos da Amazônia. Manaus: Fundação Universidade do Amazonas/INPA, 1993. 114p. (Dissertação - Mestrado). (M, PO)

MARQUES-SOUZA, A.C. Fontes de pólen exploradas por Melipona compressipes manaosensis (Apidae: Meliponinae), abelha da Amazônia Central. Acta Amazônica, v.26, p.77-86, 1996. (M, PO)

MARQUES-SOUZA, A.C. Características da coleta de pólen de alguns meliponíneos da Amazônia Central. Manaus: Fundação Universidade do Amazonas/INPA, 1999. 250p. (Tese - Doutorado). (M, PO)

MARQUES-SOUZA, A.C.; KERR, W.E. Mel amargo de breu (Protium sp., Burseraceae). Acta Amazônica, v.33, p.339-340, 2003. (A, HO)

MARQUES-SOUZA, A.C.; ABSY, M.L.; CONDÉ, P.A.A.; COELHO, H.A. Dados da obtenção de pólen por operárias de Apis mellifera no município de Ji-Paraná (RO), Brasil. Acta Amazônica, v.23, p.59-76, 1993. (A, $\mathrm{PO})$

MARQUES-SOUZA, A.C.; ABSY, M.L.; KERR, W.E.; PERALTA, F.J.A. Pólen coletado por duas espécies de meliponíneos (Hymenoptera: Apidae) da Amazônia. Revista Brasileira de Biologia, v.55, p.855-864, 1995. (M, PO)

MARQUES-SOUZA, A.C.; MOURA, C.O.; NELSON, B.W. Pollen collected by Trigona williana (Hymenoptera: Apidae) in Central Amazônia. Revista de Biologia Tropical, v.44, p.567-573, 1996. (M, $\mathrm{PO})$

MARQUES-SOUZA, A.C.; MIRANDA, I.P.A.; MOURA, C.O.; RABELO, A.; BARBOSA, E.M. Características morfológicas e bioquímicas do pólen coletado por cinco espécies de Meliponíneos da Amazônia Central. Acta Amazônica, v.32, p.217-229, 2002. (CH, M, PO)

MORETI, A.C.C.C.; CARVALHO, C.A.L.; MARCHINI, L.C.; OLIVEIRA, P.C.F. Espectro polínico de amostras de mel de Apis mellifera L., coletadas na Bahia. Bragantia, v.59, p.1-6, 2000. (A, HO)

MORETI, A.C.C.C.; MARCHINI, L.C.; SOUZA, V.C.; RODRIGUES, R.R. Atlas do pólen de plantas apícolas. Rio de Janeiro: Papel Virtual Editora, 2002. 89p. (A, PO)

OLIVEIRA, F.P.M. A vegetação secundária no município de Igarapé-Açu e seu reflexo no espectro polínico de Apis mellifera L. Belém: FCAP, 1997. 102p. (Dissertação - Mestrado). (A, HO)

OLIVEIRA, F.P.M. Recurso polínico utilizado por abelhas sem ferrão (Apidae, Meliponinae) em um fragmento florestal urbano na Amazônia. Manaus: UFA/INPA, 2003. 121p. (Tese - Doutorado). (M, HO, PO)

OLIVEIRA, F.P.M.; CARREIRA, L.M.M.; JARDIM, M.A.G. Caracterização polínica do mel de Apis mellifera L. em área de floresta secundária no município de Igarapé-Açu, Pará. Boletim do Museu Paraense Emílio Goeldi. Série Botânica, v.14, p.159-178, 1998. (A, $\mathrm{HO})$

RAMALHO, M. Foraging by stingless bees of the genus Scaptotrigona (Apidae, Meliponinae). Journal of Apicultural Research, v.29, p.6167, 1990. (HO, M, PO)

RAMALHO, M.; IMPERATRIZ-FONSECA, V.L.; KLEINERTGIOVANNINI, A.; CORTOPASSI-LAURINO, M. Exploitation of floral resources by Plebeia remota Holberg (Apidae, Meliponinae). Apidologie, v.16, p.307-330, 1985. (M, PO)
RAMALHO, M.; KLEINERT-GIOVANNINI, A.; IMPERATRIZFONSECA, V.L. Utilization of floral resources by species of Melipona (Apidae, Meliponinae): floral preferences. Apidologie, v.20, p.185-195, 1989. (M, PO)

RAMALHO, M.; KLEINERT-GIOVANNINI, A.; IMPERATRIZFONSECA, V.L. Important bee plants for stingless bees (Melípona and Trigonini) and africanized honeybees (Apis mellifera) in neotropical habitats: a review. Apidologie, v.21, p.469-488, 1990. (A, M, PO)

RAMALHO, M.; GUIBU, L.S.; GIANNINI, T.C.; KLEINERTGIOVANNINI, A.; IMPERATRIZ-FONSECA, V.L. Characterization of some southern Brazilian honey and bee plants through pollen analysis. Journal of Apicultural Research, v.30, p.81-86, 1991. (A, HO)

RAMALHO, M.; GIANNINI, T.C.; MALAGODI-BRAGA, K.S.; IMPERATRIZ-FONSECA, V.L. Pollen harvest by stingless bee foragers (Hymenoptera, Apidae, Meliponinae). Grana, v.33, p.239-244, 1994. (M, PO)

REIS, V.D.A. Fatores que influenciam na coleta de pólen por Apis mellifera L. e análise físico-química de pólen coletado. Piracicaba: USP/ESALQ, 2000. 76p. (Dissertação - Mestrado). (A, CH, PO)

SANTOS, C.F.O. Morfologia e valor taxonômico do pólen das principais plantas apícolas. Piracicaba: USP/ESALQ, 1961a. 92p. (Tese - LivreDocência). (A, PO)

SANTOS, C.F.O. Principais tipos de pólen encontrados em algumas amostras de mel: nota prévia. Revista de Agricultura, v.36, p.93-96, 1961b. (A, $\mathrm{HO})$

SANTOS, C.F.O. Características morfológicas dos grãos de pólen das principais plantas apícolas. Anais da ESALQ, v.20, p.175-228, 1963. (A, PO)

SANTOS, C.F.O. Avaliação do período de florescimento das plantas apícolas no ano de 1960, através do pólen contido nos méis e dos coletados pelas abelhas (Apis mellifera L.) Anais da ESALQ, v.21, p.253-264, 1964. (A, HO, PO)

SANTOS, C.F.O. Morfologia do pólen de algumas compostas apícolas. Anais da ESALQ, v.35, p.441-456, 1978. (A, HO, PO)

SANTOS, I.A. Melittophilous plants, their pollen and flower visiting bees in Southern Brazil: 3. Pontederiaceae. Biociências, v.5, p.3-18, 1997. (A, PO)

SANTOS, T.C.T. Dados da obtenção de pólen por operárias de Melipona seminigra merrillae Cock. em Manaus. Manaus: Fundação Universidade do Amazonas/INPA, 1991. 92p. (Dissertação - Mestrado). (M, PO)

SCHLINDWEIN, C. Melittophilous plants, their pollen and flower visiting bees in Southern Brazil: 2. Cactaceae. Biociências, v.3, p.35-71, 1995. $(\mathrm{A}, \mathrm{PO})$

SILVA, S.J.R. Recursos tróficos de abelhas Apis mellifera L. (Hymenoptera, Apidae) em uma área de savana do estado de Roraima: fontes de néctar e pólen. Manaus: Fundação Universidade do Amazonas/INPA, 1998. 88p. (Dissertação - Mestrado). (A, HO, PO)

SILVA, S.J.R.; ABSY, M.L. Análise de pólen encontrado em amostras de mel de Apis mellifera L. (Hymenoptera, Apidae) em uma área de savana de Roraima, Brasil. Acta Amazônica, v.30, p.579-588, 2000. (A, HO)

SODRÉ, G.S. Características físico-químicas e análises polínicas de amostras de méis de Apis mellifera L. 1758 (Hymenoptera: Apidae) da região litoral norte do Estado da Bahia. Piracicaba: USP/ESALQ, 2000. 83p. (Dissertação - Mestrado). (A, CH, HO)

SODRÉ, G.S.; MARCHINI, L.C.; MORETI, A.C.C.C.; CARVALHO, C.A.L. Análise polínica de méis de Apis mellifera L., 1758 (Hymenoptera: Apidae) do litoral norte do Estado da Bahia. Revista de Agricultura, v.76, p.215-225, 2001. (A, HO)

WITTMANN, D.; SCHLINDWEIN, C. Melittophilous plants, their pollen and flower visiting bees in Southern Brazil: 1. Loasaceae. Biociências, v.3, p.19-34, 1995. (A, PO)

$\overline{\text { Received August }}$ 21, 2003

Accepted March 15, 2004 